\title{
Instruments for ensuring the balanced development of maritime and inland waterway transport in Ukraine
}

\author{
Svitlana Ilchenko $^{1, *}$, Nina Khumarova $^{1}$, Natalia Maslii $^{1,2}$, Maryna Demianchuk ${ }^{1,2}$, and \\ Valerijs Skribans ${ }^{3}$ \\ ${ }^{1}$ Institute of Market Problems and Economic-Ecological Research of the National Academy of \\ Sciences of Ukraine, 29 Frantsuzkiy Blvd., 65044 Odessa, Ukraine \\ ${ }^{2}$ Odessa I.I. Mechnikov National University, 24/26 Frantsuzkiy Blvd., 65058 Odessa, Ukraine \\ ${ }^{3}$ Riga Technical University, 6 Kalnciema str. LV-1658, Riga, Latvia
}

\begin{abstract}
In this paper, present the appropriate tools for the balanced development of maritime and inland waterway transport in Ukraine to ensure the implementation of the country's economic, social and environmental plans. Using statistical data, the main indicators of the development of waterway transport in Ukraine are systematized, which indicate a lack of a technical base for a high-quality and balanced development of waterway transport in Ukraine, irrational use of the territory and water area of ports, their infrastructure, transport routes, as well as a decrease in business entities, which negatively affects the economy country. This points to the need to stimulate the development of waterway transport to increase the number of jobs, improve living conditions of the population, curb migration processes and retain qualified personnel, unload land transport, and save money on road repairs. Therefore, in order to ensure the implementation of the country's economic, social and environmental plans, an instrumental-logical model has been developed to ensure the co-evolutionary balanced development of water transport in Ukraine, which is based on the use of institutional, legal, financial, economic and information and communication tools.
\end{abstract}

\section{Introduction}

In modern conditions of Ukrainian economy development, which are characterized by the strengthening of integration processes into the world economic system, the development of the transport system and its effective functioning is of prime importance. At the moment, there are imbalances in the transportation of passengers and goods by different modes of transport, in particular, the carriage by road is leading on the Ukrainian market. However, given the ecological situation in the world and in Ukraine, it is advisable to develop more economical and environmentally efficient modes of transport, namely waterway transport. With sufficient intensification and balance of transportation, the development of waterway

\footnotetext{
* Corresponding author: ilchenko.svit@gmail.com
} 
transport can have a multiplier economic effect on other areas of economic activity, whose enterprises produce products that require transportation to consumers. Since the use of vessels of various types of waterway transport, including maritime, inland and mixed, which are capable of transporting heavy cargo, leads not only to a reduction in the costs of the manufacturer of products for transportation, thereby reducing the cost of production and increasing its competitiveness, but also to decrease the pollutant emissions, substances into the atmosphere and the environment. Thus, it is relevant to develop an instrumental-logical model for ensuring the balanced development of waterway transport in Ukraine on the basis of systematization and analysis the main economic, environmental and social indicators.

\section{Literature review}

Scientists from different countries are investigating the problems of ensuring a balanced development of transport as a way to mitigate the effects of climate change. For example, authors from Australia, China, and Singapore, based on a review of scientific literature, identified nine relevant topics for the study of sustainable transport, covering development indicators, efficiency models, supply chains, stakeholder participation, new fuels and environmental impacts [1]. One of these modes of transport is waterway transport, where research emphasizes the importance of development in ensuring global sustainability in a business context and involving stakeholders in the planning and management of sustainable maritime and inland waterway transport activities, affecting their attractiveness in terms of the development of international cooperation $[2,3]$.

Based on a case study of the European inland waterway transport sector, scientists [4] have proposed five pathways to a sustainable European inland navigation sector that will enhance their competitiveness through the use of various types of innovations. S. Tsani, $\mathrm{Ph}$. Koundouri and E. Akinsete [5] by identifying complementary inconsistencies with the global sustainable development of some river basins of the European Union (in particular Adige, Anglian, Ebro, Evrotas, Sava) propose to improve the implementation of European Union policy using economic instruments and supporting methodologies that take into account social, economic and environmental aspects of water resources management. The developed model of the system of indicators for assessing the sustainability of water resources in river basins [6] is useful in diagnostics and forecasting of sustainable development of water resources, taking into account the problems of the socio-ecological system of territories.

Important socially significant issues are not only the provision of jobs in the territories and material remuneration of workers in the transport sector, but also the development of the public transport system in the country's territories to ensure the accessibility of the population to it [7]. The authors of [8], using the example of Austria, investigate the development of effective and balanced transport policy packages, the basis of which is the provision of infrastructure and spatial planning. R. Strulak-Wójcikiewicz and J. Lemke [9] based on the use of a dynamic approach, the concept of a simulation model for assessing public transport in the economic, social and environmental dimension is presented, which made it possible to integrate numerous indicators and determine the degree of sustainable development.

Considering that technological innovations play an important role in the process of ensuring the sustainable development of waterway transport, it is necessary to solve the environmental problems arising from the activities of maritime and inland waterway transport. In particular, the development of waterway transport can make the main contribution to the preservation and rational use of the oceans, seas and inland water resources $[10,11]$. D. Gupta and A. Garg [12] identified the implications of the dynamics of the transport sector for the energy, environment and economy of India by conducting a 
comprehensive analysis using a new methodological approach aimed at implementing a scenario that assumes a significant reduction in fuel imports and foreign exchange savings. Also, using the example of London [13], the application of the method of prioritizing the introduction of zones with zero carbon emissions is considered, which makes it possible to switch to the most environmentally sustainable modes of transport.

It should be noted that a number of strategic documents of Ukraine provide for priority tasks requiring immediate solution, in particular, by the Decree of the President of Ukraine "On the Sustainable Development Goals of Ukraine until 2030" [14], Orders of the Cabinet of Ministers of Ukraine "On the approval of the National Transport Strategy of Ukraine for the period until 2030 year" [15] and "On approval of the Strategy for the development of seaports of Ukraine for the period up to 2038" [16], the Law of Ukraine "On Inland Water Transport" [17], the Maritime Doctrine of Ukraine [18], as well as other important regulatory legal documents and strategic development plans for the medium and short term of the Ministry of Infrastructure of Ukraine, the Administration of Seaports (USPA) and the Administration of River Ports of Ukraine, etc.

For the development of the Ukrainian economy, the questions identified by Ukrainian scientists need further research. Problems and prospects in change management within the framework of the European green deal are important for achieving sustainable development goals [19]. The need to achieve a balance between economic efficiency and environmental and social responsibility of the enterprise [20] is stipulated to manage their competitiveness [21]. Study of the risks and threats of the provision of transport services [22] from the perspective of ensuring the balanced development of seaports with sufficient land infrastructure and its effective use on an innovative basis [23], introducing the experience of international practice in the sustainable development of the port economy [24]. The need for a dynamic and balanced development of the transport system and its infrastructure is due to the integration of the Ukrainian economy into the European space [25].

Thus, scientists emphasize the obvious importance and lack of attention to the implementation of the global sustainable development goals and the goals of each individual country on the part of waterway transport. Therefore, it is necessary to consider various aspects of the balanced development of maritime and inland waterway transport in Ukraine, as a country participating in the functioning of the Black Sea-Azov basin, which is part of the water sections of international transport corridors, in order to create and promote new trade routes.

The purpose of the paper is to identify the most appropriate instruments for the balanced development of maritime and inland waterway transport in Ukraine to ensure the implementation of the country's economic, social and environmental plans.

\section{Material and methods}

To carry out the research, the results of scientific works of leading scientists in the field of the main directions of the balanced development of maritime and inland waterway transport, in particular economic, environmental and social aspects, were studied and summarized. Applying a systematic approach in conjunction with methods of comparison, observation and structural-functional analysis, the problem areas of the transport sector are elaborated and the relationships between various economic, social and environmental processes are established using retrospective statistical data and graphical presentation of information. Based on the concept of a deterministic approach using situational modeling, an instrumental-logical model has been developed to ensure the balanced development of maritime and inland waterway transport in Ukraine. Using the method of predictive analysis, the economic, environmental and social results of the balanced development of water transport in Ukraine are highlighted. 


\section{Results and discussion}

According to the analysis of the gross domestic product (GDP) of Ukraine for 2016-2019 by the production method by type of economic activity, the transport system ranks fourth in the production of goods and services, which in percentage terms is $6.51 \%$, behind the processing industry $(24.98 \%)$. wholesale and retail trade $(11.88 \%)$ and agriculture, forestry and fisheries $(10.6 \%)$. Table 1 data indicate a constant positive dynamics of changes in GDP, however, the share of the transport sector in the structure of GDP has an unstable dynamics, which indicates the existing problem areas that require appropriate solutions.

When making effective decisions in the field of transport, it is also necessary to take into account that, in accordance with the classification of types of economic activity (KVED), it includes land and pipeline, waterway and air transport.

Table 1. Dynamics of changes in GDP and the share of the transport sector in it.

\begin{tabular}{|l|c|c|c|c|}
\hline \multirow{2}{*}{ Indicators Gross domestic product } & \multicolumn{4}{c|}{ Years } \\
\cline { 2 - 5 } & 2016 & 2017 & 2018 & 2019 \\
\hline Goods and services output at market prices, mln UAH & 4665935 & 5593790 & 6956086 & 8323777 \\
\hline Transportation and storage, mln UAH & 306047 & 354332 & 426602 & 542113 \\
\hline Specific gravity Transportation from GDP, \% & 6.56 & 6.33 & 6.13 & 6.51 \\
\hline
\end{tabular}

Source: created by the authors based on data [26].

In turn, waterway transport is classified according to the type of vehicle used for the transport of passengers and goods, in particular, passenger maritime transport, freight maritime transport, passenger river transport and freight river (inland waterway) transport. According to the authors, and taking into account the goals of sustainable development of the world and Ukraine, special attention is required both for freight water transport, the development of which must be considered as one of the important criteria for ensuring economic development, and passenger waterway transport, which is not only an economic incentive for the development of territories (cruise tourism), but an important social factor in the balanced development of the country.

\subsection{Systematization of the main indicators of the development of waterway transport in Ukraine}

Waterway transport of Ukraine is a multifunctional structural unit of the national economy, which is of great importance for various spheres of economic activity and trade development, since the use of maritime and inland waterway transport can significantly reduce the cost of transporting products to consumers and is at the same time an energysaving and environmentally friendly mode of transport. At the moment, on the territory of Ukraine, in the Black Sea-Azov basin and the Danube delta, there are 18 seaports, among which 5 are located in the temporarily occupied territory of the Autonomous Republic of Crimea, as well as 16 river ports and terminals.

The length of the mooring front of the seaports of Ukraine is about $40 \mathrm{~km}$, and the length of the canals is $124,768 \mathrm{~km}$. The total length of the navigable rivers of Ukraine, used as waterways, is $2241 \mathrm{~km}$. Of the three ship-floating rivers of the $\mathrm{r}$. The Dnieper is the most important waterway, the basin of which occupies about $65 \%$ of the river space of Ukraine. A number of international transport corridors pass through the territory of Ukraine, some sections of which are served by waterway transport. In particular, the TRACECA corridor, Pan-European transport corridors № 7 and № 9, transport routes of the EU countries - China ("Economic Belt of the Silk Road"), waterway E-40 (Baltic Sea - Black Sea) and others.

At the end of 2019, waterway transport is represented by 255 business entities, including 126 units (49.4\%) are individuals, entrepreneurs, most of which carry out passenger 
transportation. The freight maritime and inland waterway transport accounts for 76 and 35 economic entities, respectively (Table 2). It should be noted that large business entities are not represented on the market, that is, business entities of any organizational and legal form and form of ownership, in which the average number of people per calendar year exceeds 250 persons and the annual income from any activity exceeds an amount equivalent to 50 million euros in the average annual rate of the National Bank of Ukraine [27]. Most of the business entities involved in the carriage of goods by sea are small businesses.

Note that in accordance with the data [28] in Ukraine at the end of 2019 there were registered 694 marine vessels, 1284 river vessels, 184 vessels of a mixed navigation area, 9594 pleasure craft with an engine capacity of $75 \mathrm{hp}$. and more.

However, according to 2017 data, the number of marine vessels was 3334 units and river vessels - 1401 units. Both among marine and river vessels, dry cargo prevails in type (sea $-38.4 \%$, river $-32.5 \%$ ).

Table 2. Number of water transport enterprises in Ukraine.

\begin{tabular}{|l|c|c|c|c|}
\hline \multicolumn{1}{|c|}{ Indicators } & \multicolumn{3}{c|}{ Years } \\
\cline { 2 - 5 } & 2016 & 2017 & 2018 & 2019 \\
\hline Number of business waterway transport (units), including & 279 & 248 & 235 & 255 \\
\hline - medium entrepreneurship entities & 3 & 5 & 6 & 9 \\
\hline - small entrepreneurship entities & 276 & 243 & 229 & 246 \\
\hline 1. Marine and coastal freight waterway transport, including & 71 & 68 & 67 & 76 \\
\hline - medium entrepreneurship entities & 1 & 2 & 3 & 6 \\
\hline - small entrepreneurship entities & 70 & 66 & 64 & 70 \\
\hline 2. Marine and coastal passenger water transport, including & 97 & 70 & 67 & 71 \\
\hline - medium entrepreneurship entities & - & - & 1 & 1 \\
\hline - small entrepreneurship entities & 97 & 70 & 66 & 70 \\
\hline 3. Inland freight waterway transport, including & 33 & 33 & 32 & 35 \\
\hline - medium entrepreneurship entities & 2 & 2 & 2 & 2 \\
\hline - small entrepreneurship entities & 31 & 31 & 30 & 33 \\
\hline 4. Inland passenger waterway transport, including & 78 & 77 & 69 & 73 \\
\hline - medium entrepreneurship entities & - & 1 & - & - \\
\hline - small entrepreneurship entities & 78 & 76 & 69 & 73 \\
\hline
\end{tabular}

Source: created by the authors based on data [26].

The average age of the marine and river fleet is $25-30$ years. The replenishment of the marine and river fleets is practically not carried out, and the ship automation systems do not fully meet modern requirements.

Table 3. River and marine vessels by types (units).

\begin{tabular}{|l|c|c|c|c|c|c|}
\hline \multirow{2}{*}{ Vessels by types } & \multicolumn{3}{c|}{ River vessels } & \multicolumn{3}{c|}{ Marine vessels } \\
\cline { 2 - 7 } & 2015 & 2016 & 2017 & 2015 & 2016 & 2017 \\
\hline Passenger & 151 & 151 & 166 & 103 & 105 & 131 \\
\hline Tanker vessels & - & - & - & 11 & 11 & 27 \\
\hline Dry-cargo ships & 440 & 438 & 455 & 1118 & 1123 & 1280 \\
\hline Tanker vessels (dump) & - & - & - & 41 & 40 & 79 \\
\hline special purpose & 245 & 242 & 257 & 588 & 586 & 847 \\
\hline technical & 93 & 92 & 107 & 183 & 182 & 242 \\
\hline service and auxiliary & 392 & 389 & 416 & 327 & 327 & 608 \\
\hline Fishing vessel, from them & - & - & - & 114 & 117 & 120 \\
\hline industrial & - & - & - & 105 & 111 & 114 \\
\hline industrial processing & - & - & - & 9 & 6 & 6 \\
\hline Total & 1321 & 1312 & 1401 & 2485 & 2491 & 3334 \\
\hline
\end{tabular}

Source: created by the authors based on data [26]. 
In general, over the past 10 years, the number of business entities has decreased by half, and in their structure, mainly small businesses. Considering the number of marine and river vessels, as well as the degree of their wear and tear, there is a lack of a technical base for a high-quality and balanced development of waterway transport in Ukraine. There is a need to analyze the activities of enterprises of maritime and inland waterway transport in the context of economic, social and environmental components, which will identify reserve resources that will ensure the balanced development of waterway transport. At the same time, the rational use of the territory and water wayarea of ports, their infrastructure, transport routes, and the fleet is important for building an effective balanced waterway transport system, especially when integrating transportation with other modes of transport on the principles of intermodality and multimodality.

\subsection{Analysis of the economic potential of the marine and inland waterway transport of Ukraine, its impact on the environment and social significance}

\subsubsection{Analysis of the economic development potential of maritime and inland waterway transport in Ukraine}

Studies have shown that in the structure of the volume of products sold by waterway transport over the past 4 years there have been cardinal changes (Table 4 ).

Table 4. Economic indicators of the development of water transport.

\begin{tabular}{|l|c|c|c|c|}
\hline \multirow{2}{*}{ Indicators } & \multicolumn{4}{c|}{ Years } \\
\cline { 2 - 5 } & 2016 & 2017 & 2018 & 2019 \\
\hline 1. Freight turnover of waterway transport, billion tkm & 4.0 & 4.3 & 3.4 & 3.4 \\
\hline 1.1. Maritime and coastal freight waterway transport & 2.5 & 2.9 & 1.8 & 1.8 \\
\hline 1.2. Inland freight waterway transport & 1.5 & 1.4 & 1.6 & 1.6 \\
\hline 2. Passenger turnover of waterway transport, thous. pas. km & 30392.4 & 30348.9 & 27600.6 & 25788.4 \\
\hline 2.1. Maritime and coastal passenger waterway transport & 17838.3 & 10781.8 & 2088.9 & 1325.9 \\
\hline 2.2. Inland passenger waterway transport & 12554.1 & 19567.1 & 25511.7 & 24462.5 \\
\hline 3. Export / Import of waterway transport service & & & & \\
\hline 3.1. Export of maritime transport services, thous. USD & 735935.8 & 661619.1 & 612112.3 & 523257.5 \\
\hline \% of total exports of transport services, \% & 14.0 & 12.5 & 10.4 & 8.9 \\
\hline 3.2. Import of maritime transport services, thous. USD & 191729.0 & 141180.7 & 222770.1 & 222986.3 \\
\hline \% of total imports of transport services, \% & 16.6 & 14.3 & 18.4 & 15.2 \\
\hline 3.3. Import of river transport services, thous.USD & 600.8 & 351.1 & $\mathrm{c}$ & $\mathrm{c}$ \\
\hline \% of total imports of transport services, \% & 0.1 & 0.0 & $\mathrm{c}$ & $\mathrm{c}$ \\
\hline 4. Net profit, thous. UAH & 22681.2 & 70683.6 & 54311.9 & 213365.1 \\
\hline 4.1. Maritime and coastal freight water transport & 49425.1 & 49006.3 & 204281.4 & 49425.1 \\
\hline 4.2. Inland freight water transport & $\mathrm{c}$ & $\mathrm{c}$ & $\mathrm{c}$ & $\mathrm{c}$ \\
\hline 4.3. Maritime and coastal passenger waterway transport & -366.8 & $\mathrm{c}$ & $\mathrm{c}$ & $\mathrm{c}$ \\
\hline 4.4. Inland passenger waterway transport & -15665.0 & -5741.0 & -8989.6 & 2784.2 \\
\hline 5. Profitability of operational activity of enterprises, \% & 2.0 & 1.9 & 1.7 & 6.9 \\
\hline 5.1. Maritime and coastal freight waterway transport & $\mathrm{c}$ & 7.6 & 3.2 & 10.5 \\
\hline 5.2. Inland freight waterway transport & $\mathrm{c}$ & $\mathrm{c}$ & $\mathrm{c}$ & $\mathrm{c}$ \\
\hline 5.3. Maritime and coastal passenger waterway transport & -1.9 & $\mathrm{c}$ & $\mathrm{c}$ & $\mathrm{c}$ \\
\hline 5.4. Inland passenger waterway transport & -46.7 & -4.6 & -15.5 & 57.3 \\
\hline
\end{tabular}

$c$ - Data are not published in order to ensure compliance with the requirements of the Law of Ukraine On the State Statistics regarding confidentiality of statistical information (primary and secondary blocking of vulnerable values).

Source: created by the authors based on data [26]. 
For example, $67.17 \%$ of products were sold by freight sea transport in 2019 , in contrast to $31.48 \%$ in 2016 . However, despite the fact that there are fewer medium-sized businesses in terms of number, they account for the predominant volume of products sold in 2019: marine freight transport $-86.63 \%$, inland waterway $-88.92 \%$.

In comparison with other modes of transport, waterway transport is the least used in the transportation of goods and passengers, since it accounts for less than $1 \%$ of both the transportation of goods and passengers. At the same time, $2 / 3$ of waterway transport cargoes and about $88 \%$ of passengers are transported by river transport. Cargo turnover, as well as passenger turnover, of waterway transport over the past 4 years has decreased by $15 \%$, mainly due to a drop in the carriage of goods and passengers by maritime transport.

The economic indicators of the development of waterway transport show that, in contrast to the volume of export of transport services of maritime transport, which during the period under review decreased by $19.0 \%$, the volume of import of transport services increased by $42.8 \%$. There is also a decrease in imported river transport services. Operating profitability during 2016-2018 was rather low, but in 2019 it is $6.9 \%$. At the same time, the net profit of enterprises increased tenfold, the main part of which is formed by the enterprises of cargo maritime transport. Thus, waterway transport enterprises have sufficient financial and economic prerequisites to ensure balanced development.

\subsubsection{Impact of maritime and inland waterway transport on the environment}

An increase in the technogenic load on the environment leads to significant changes in the climate and ecology of the world as a whole, Ukraine is no exception. The activity of any type of transport affects the environment through the emission of pollutants and greenhouse gases into the air. Data from the Environmental Performance Index (EPI) [29], which assesses countries in terms of the state of the environment and the viability of ecosystems, indicate good results for Ukraine in terms of environmental indicators. In particular, the EPI rating of Ukraine in 2020 was 49.5 (60th out of 180). There are tendencies of a decrease in the intensity of greenhouse gases, a reduction in emissions of pollutants. At the same time, the main air pollutants (emissions of pollutants account for more than $90 \%$ of the total emissions into the atmospheric air in Ukraine) are enterprises of the extractive and processing industries, suppliers of electricity, gas and conditioned air.

Among all types of transport, according to [30], road transport has the greatest negative impact on the atmospheric air, its emissions in recent years have reached $35 \%$ of the total emissions of pollutants, which in 2018 amounted to 1,358.4 thsd tons. When using railway transport during $2018,101.382$ thsd tons of waste were generated, of which 0.148 thsd tons - I hazard class; 0.930 thsd tons - II class of hazard; 22.450 thsd tons - III hazard class; 77.854 thsd tons - IV hazard class. Emissions from waterway transport in 2018 amounted to 527,722 tons; volumes of pollutants discharged into water bodies $-359,100$ tons. At the same time, for further safe handling, specialized enterprises received hazard class I waste 2.549 tons; II class of danger -6.717 tons; III hazard class -61.419 tons.

Such a load on the environment indicates the need to transfer a significant part of the freight traffic of road transport to other types, in particular, maritime and inland waterways, the environmental hazard of which is minimal. However, such a danger exists, which can lead to pollution of sea and river waters, caused by two reasons (operational activities and accidents). As a result of the operation of ships, water areas are polluted by ship engines (emissions of exhaust gases), waste and oily waters; in case of accidents, water pollution occurs with oil products and other toxic substances. The amount of carbon dioxide emitted by a ship is influenced by a wide range of parameters, in particular the type of ship, speed, size, hull design, ballast, technologies and types of fuels used. Naturally, a larger ship will emit more carbon dioxide. However, on a per ton-mile basis, large ships emit significantly 
less carbon dioxide than small ships. It should be noted that in 2018 expenditures were made for environmental protection in the amount of UAH $150.927 \mathrm{mln}$, including measures for the protection of atmospheric air -422.6 thsd UAH, water environment $-56.528 \mathrm{mln}$ UAH, safe waste management - $56.329 \mathrm{mln} \mathrm{UAH}$.

The member countries of the International Maritime Organization, with other international organizations and partners, strive to reduce emissions from shipping through the use of low-cost, low-carbon energy sources. The development of such a direction in shipping will minimize the impact on the environment, and will also contribute to the decarbonization of the economy and reduce the energy intensity of GDP, the value of which in 2019 is 0.092 toe / thsd international dollars for final energy consumption $(2007-0.144)$ and 0.165 toe / thsd international dollars for total primary energy supply $(2007-0.234)$.

Maritime and inland waterway transport of Ukraine is able to increase environmental sustainability and competitiveness at the international level through the renewal of the fleet, the use of new technologies and environmentally friendly alternative fuels, and the modernization of the energy infrastructure of waterway transport.

\subsubsection{Analysis of the social significance of the development of inland waterway and maritime transport in Ukraine}

Waterway transport enterprises are strategically important for the social development of both individual territories and the entire country as a whole, since they satisfy the need for freedom of spatial mobility of the population, in particular, the provision of reliable and high-quality services to passengers, providing convenient access to places of work, the service sector, to medical, educational and cultural institutions. It plays an especially important role in ensuring the life of those territories where the density of railways and highways is low or in an unsatisfactory condition, and the network of inland waterways is well developed. Therefore, passenger transport services are socially important services, forming transport links.

Table 5. The number of employed workers at waterway transport enterprises and their average wages

\begin{tabular}{|l|c|c|c|c|}
\hline \multicolumn{1}{|c|}{ Indicators } & \multicolumn{4}{c|}{ Years } \\
\cline { 2 - 5 } & 2016 & 2017 & 2018 & 2019 \\
\hline $\begin{array}{l}\text { 1. Number of persons employed of entities of waterway transport } \\
\text { enterprises, persons }\end{array}$ & 4418 & 4100 & 3975 & 4266 \\
\hline - medium entrepreneurship entities & 3449 & 3245 & 3150 & 3347 \\
\hline - small entrepreneurship entities & 969 & 855 & 825 & 919 \\
\hline 1.1. Maritime and coastal freight waterway transport, persons & 486 & $\mathrm{c}$ & $\mathrm{c}$ & 2004 \\
\hline - medium entrepreneurship entities & 59 & $\mathrm{c}$ & $\mathrm{c}$ & 1532 \\
\hline - small entrepreneurship entities & 427 & 393 & 413 & 472 \\
\hline 1.2. Maritime and coastal passenger waterway transport, persons & 144 & 114 & 165 & $\mathrm{c}$ \\
\hline - medium entrepreneurship entities & - & - & 68 & $\mathrm{c}$ \\
\hline - small entrepreneurship entities & 144 & 114 & 97 & $\mathrm{c}$ \\
\hline 1.3. Inland freight waterway transport, persons & 3663 & $\mathrm{c}$ & $\mathrm{c}$ & $\mathrm{c}$ \\
\hline - medium entrepreneurship entities & 3390 & $\mathrm{c}$ & $\mathrm{c}$ & $\mathrm{c}$ \\
\hline - small entrepreneurship entities & 273 & 225 & $\mathrm{c}$ & $\mathrm{c}$ \\
\hline 1.4. Inland passenger waterway transport, persons & 125 & 218 & 133 & 120 \\
\hline - medium entrepreneurship entities & - & 95 & - & - \\
\hline - small entrepreneurship entities & 125 & 123 & 133 & 120 \\
\hline $\begin{array}{l}\text { 2. Average monthly wages of regular employee's waterway transport (wage } \\
\text { accruals per pay-roll), UAH }\end{array}$ & 6974 & 7590 & 10467 & 13057 \\
\hline Soure
\end{tabular}

Source: created by the authors based on data [26].

Considering the enterprises of waterway transport that promote employment, it should be noted that they employ $0.06 \%$ of the total number of employed workers in all spheres of 
economic activity. At the same time, the majority work on inland waterway transport, but their number is rapidly decreasing every year, however, a more detailed analysis cannot be carried out due to the confidentiality of statistical information. During the analyzed period, the salary of the staff of the waterway transport doubled. At the same time, the salary of $62 \%$ of full-time employees is in the range of 7.0-20.0 thsd UAH; wages of $25.5 \%$ of fulltime employees are less than 7.0 thsd UAH and $12.5 \%$ more than 20.0 thsd UAH.

The economic activity of waterway transport enterprises affects not only the level of employment and wages of individuals, but also directly on the development of the region where these enterprises are present. With the development of waterway transport enterprises, additional jobs are created not only in this industry, but also in related ones. They participate in the formation of the budget of the region of presence and develop its infrastructure, increasing the investment attractiveness of the regions. Being important links of trade, the enterprises of the water area maintain an effective partnership of territorial communities with the regional and international trade community, thereby ensuring foreign economic relations and integration processes.

Thus, the development of waterway transport has not only a stimulating effect on the economic growth of territorial communities, entrepreneurial activity and competition in the market, but also on the inflow of investments, contributing to the development of innovative technologies, curbing migration processes and retaining qualified personnel. All this helps to reduce social tension and improve living conditions of the population, harmonious development and consolidation of society, popularization of Ukraine in the world. It should also be noted that the development of inland waterway transport contributes to saving funds for road repairs by unloading land transport.

\subsection{An instrumental-logical model for ensuring the balanced development of maritime and inland waterway transport in Ukraine}

To achieve a balanced development of the maritime and inland waterway transport of Ukraine, taking into account the existing potential, it is necessary to use effective tools to ensure such development. According to the authors, the primary instruments that can ensure the transformation of the waterway transport system from an undesirable state into a balanced equilibrium state for the harmonization of activities are institutional and legal, financial and economic, information and communication (Fig. 1).

Institutional and legal instruments are one of the essential in ensuring the balanced development of waterway transport in Ukraine, involving the implementation of coordination of actions, regular monitoring and assessment of the achievement of the balance level, taking into account compliance with the requirements of regulatory legal acts. It is also important to support territorial communities by private entrepreneurs in the development and maintenance of a development plan for the territory of presence, which contributes to integration into the global economic space, ensuring the protection of national interests and fulfilling international obligations in the field of balanced development.

Financial and economic instruments imply the use of rational taxation mechanisms that will allow applying the principles of determining the level of resource consumption and environmental pollution by entrepreneurs in order to minimize the negative impact of their activities. Improving the investment attractiveness of the territory of waterway transport enterprises presence will ensure economically justified tariffs by reducing the tax burden when using foreign investments and international financial assistance, taking into account the priority of investment goals. The development and implementation of energy-saving, low-carbon and other environmentally friendly technologies will preserve the natural resource potential of the territory of presence and its rational use with mandatory renewal. 


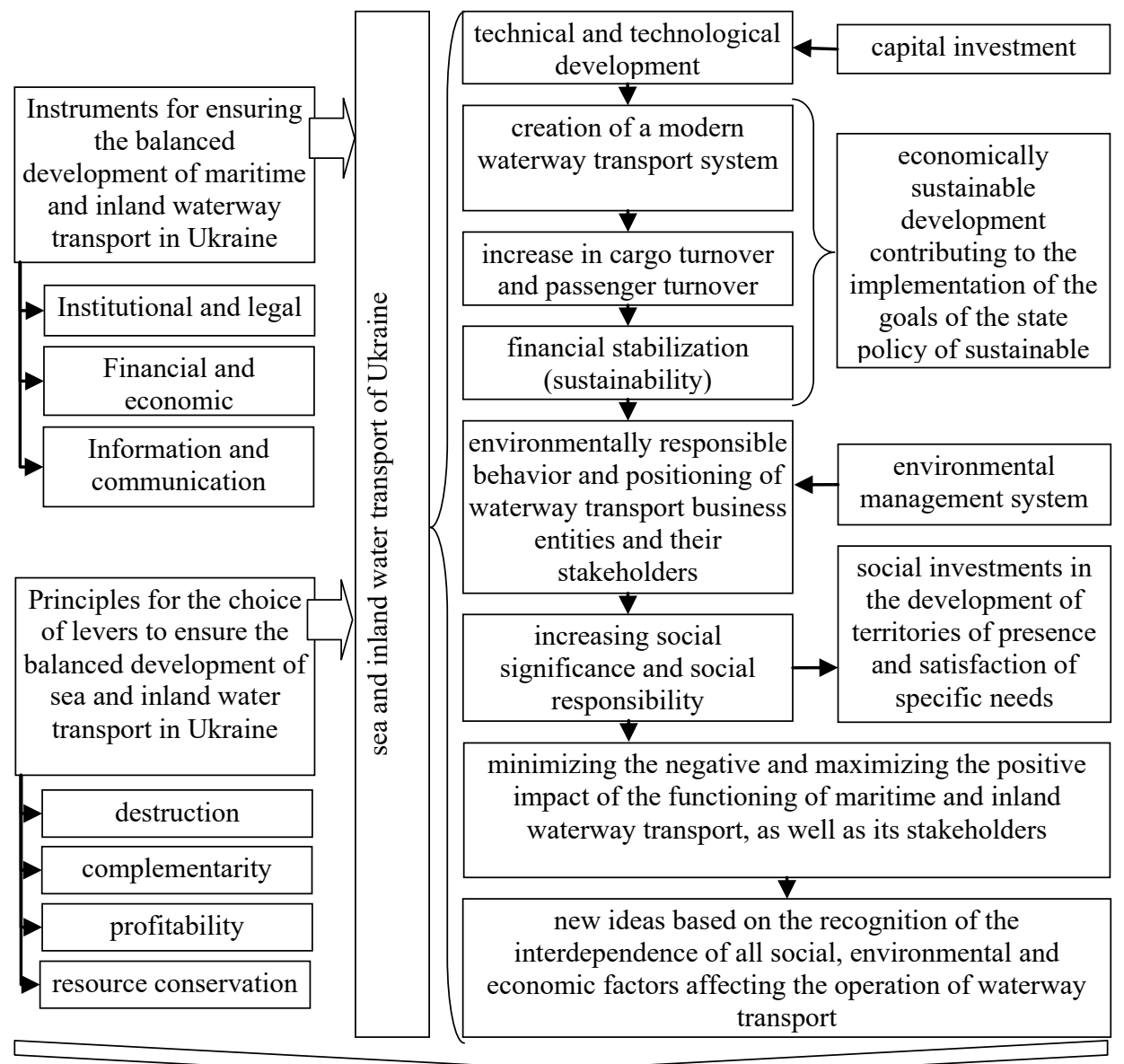

\begin{tabular}{|c|l|}
\hline \multicolumn{1}{|c|}{$\begin{array}{l}\text { Main results: } \\
\text { - transition to rational models of consumption and production; }\end{array}$} \\
- protection and restoration of ecosystems; \\
\begin{tabular}{|c|l}
\hline economic \\
- full and productive employment of the population with decent \\
working conditions;
\end{tabular} \\
$\begin{array}{l}\text { - a decrease in the energy intensity of GDP; } \\
\text { - promoting the effective integration of Ukraine into the European } \\
\text { and international economic space. }\end{array}$ \\
\hline
\end{tabular}

Fig. 1. Instrumental-logical model of ensuring the balanced development of waterway transport in Ukraine.

Information and communication tools will contribute to the innovative transformation and digitalization of waterway transport enterprises to create a single digital transport space in the country using cloud technologies, artificial intelligence, big data and others. The effective functioning of information systems contributes to an objective informationanalytical and research coalition of waterway transport stakeholders, which will allow introducing the best practices for the balanced development of maritime and inland waterway transport in Ukraine. It will also contribute to a timely deep understanding of the problems of society's transition to a model of balanced production and consumption and an appropriate response from educational institutions to train qualified specialists with sufficient competencies to solve the problems of balanced development of waterway 
transport. An increase in the speed of collection, processing, distribution, exchange and use of reliable, complete and timely information will improve the business functions of waterway transport enterprises, in particular, the functions of managing the qualifications and competence level of development of stakeholders, attitudes towards environmental problems, and ensuring the well-being of society.

However, when choosing specific security levers, one should adhere to the principles of destruction (a system leading to a dangerous result is destroyed due to the exclusion of one or several elements from it), complementarity (complementarity - ensuring a positive effect from managerial actions simultaneously in several directions), economy (maximum efficiency at minimum costs), resource conservation (planning the rational and efficient use of resources), which will allow reaching the highest point of balanced development with the highest speed of achieving efficiency. The use of the presented tools to ensure the balanced development of the maritime and inland waterway transport of Ukraine by ranking the priority development goals will allow creating a manageable economic, social and ecological system in space and time, the process of which involves the passage of a cycle of co-evolutionary development. Indeed, it is technical and technological development that requires significant capital investments aimed at creating a modern waterway transport system, including the fleet, ports and their infrastructure, multimodal logistics centers, etc., that contributes to obtaining a positive economic effect.

The economically sustainable development of maritime and inland waterway transport, at the same time contributing to the implementation of the goals of the state policy of sustainable development, is facilitated by the new technical and technological opportunities that are being created. They, in turn, lead to the emergence of new or modified functions of waterway transport. At the same time, the quantitative and qualitative increase in throughput helps to maximize the cargo and passenger traffic of maritime and inland waterway transport and the dynamic use of opportunities, which leads to financial stabilization (sustainability).

Due to the sufficient volume of financial capabilities of maritime and inland waterway transport, it is possible to implement environmentally responsible behavior and positioning of business entities in waterway transport and their stakeholders, based on the spread of the introduction of an environmental management system. It will also contribute to an increase in the social significance and social responsibility of waterway transport, attracting social investments in the development of the territories of presence and meeting specific needs.

In the process of ensuring such co-evolutionary balanced development, which minimizes the negative and maximizes the positive impact of the functioning of maritime and inland waterway transport, as well as its stakeholders, new ideas arise for the next development cycle, which is based on the recognition of the interdependence of all social, environmental and economic factors that affect their actions.

\section{Conclusions}

The use of the tools to ensure the balanced development of the maritime and inland waterways transport of Ukraine in combination will have positive results. The main economic result will be an increase in gross domestic product due to an increase in cargo turnover and passenger turnover by rhese modes of transport, an increase in the efficiency of transportation by maximizing the use of the carrying capacity of ships by improving the technical and technological characteristics of shipping routes, and an increase in the speed of ships. Also, the development of the sphere will contribute to an increase in income, profits and profitability of waterway transport enterprises, as well as the development of related areas of economic activity by increasing export, import and transit cargo. In general, 
increasing the efficiency of transportations by waterway transport of Ukraine will increase the competitiveness of enterprises in the international market.

The social result of the balanced development of waterway transport in Ukraine is the creation of new jobs, due not only to an increase in freight flows, but also in passenger traffic due to an increase in tourist flows. This will not only reduce the costs of state and local budgets for the social sphere, but also increase tax revenues. That is, the development of maritime and waterway transport of Ukraine can have a multiplicative result, causing an increase in demand for goods and services due to the growth of employment of the population of the regions of presence. The ecological result from the balanced development of waterway transport in Ukraine is also important, which is positively manifested in the reduction of $\mathrm{CO}_{2}$ emissions into the atmosphere, through the transfer of part of the freight traffic from land transport to waterway transport, renewal of the fleet and applied technologies, the use of environmentally friendly alternative fuels and other measures.

In general, ensuring the balanced development of waterway transport will ensure the transition to rational patterns of consumption and production, the protection and restoration of ecosystems, full and productive employment of the population with decent working conditions, as well as a decrease in the energy intensity of GDP, which will contribute to the effective integration of Ukraine into the European and international economic space.

\section{References}

1. Zhao, X., Ke, Y., Zuo, J., Xiong, W., \& Wu, P. (2020). Evaluation of sustainable transport research in 2000-2019. Journal of Cleaner Production, 256, 120404. https://doi.org/10.1016/j.jclepro.2020.120404.

2. Yuen, K. F., Wang, X., Wong, Y. D., \& Li, K. X. (2020). The role of stakeholder participation and sustainability integration in maritime transport: A structure-conduct$\begin{array}{llll}\text { performance } & \text { analysis. } & \text { Transport } & \text { Policy, }\end{array}$ https://doi.org/10.1016/j.tranpol.2020.08.011.

3. Bai, X., Zhang, X., Li, K. X., Zhou, Y., \& Yuen, K. F. (2021). Research topics and trends in the maritime transport: A structural topic model. Transport Policy, 102, 11-24. https://doi.org/10.1016/j.tranpol.2020.12.013.

4. Sys, C., Van de Voorde, E., Vanelslander, T., \& Van Hassel, E. (2020). Pathways for a sustainable future inland water transport: A case study for the European inland navigation sector. Case Studies on Transport Policy, 8(3), 686-699. https://doi.org/10.1016/j.cstp.2020.07.013.

5. Tsani, S., Koundouri, P., \& Akinsete, E. (2020). Resource management and sustainable development: A review of the European water policies in accordance with the United Nations' Sustainable Development Goals. Environmental Science \& Policy, 114, 570-579. https://doi.org/10.1016/j.envsci.2020.09.008.

6. Silva, J., Fernandes, V., Limont, M., Dziedzic, M., Andreoli, C. V., \& Rauen, W. B. (2020). Water sustainability assessment from the perspective of sustainable development capitals: Conceptual model and index based on literature review. Journal of Environmental Management, 254, 109750. https://doi.org/10.1016/j.jenvman.2019.109750.

7. Tiwari, G., \& Phillip, C. (2021). Development of public transport systems in small cities: A roadmap for achieving sustainable development goal indicator 11.2. IATSS Research. https://doi.org/10.1016/j.iatssr.2021.02.002.

8. Thaller, A., Posch, A., Dugan, A., \& Steininger, K. (2021). How to design policy packages for sustainable transport: Balancing disruptiveness and implementability. Transportation Research Part D: Transport and Environment, 91, 102714. https://doi.org/10.1016/j.trd.2021.102714.

9. Strulak-Wójcikiewicz, R., \& Lemke, J. (2019). Concept of a Simulation Model for 
Assessing the Sustainable Development of Urban Transport. Transportation Research Procedia, 39, 502-513. https://doi.org/10.1016/j.trpro.2019.06.052.

10. Rahdari, A., Sepasi, S., \& Moradi, M. (2016). Achieving sustainability through Schumpeterian social entrepreneurship: The role of social enterprises. Journal of Cleaner Production, Volume 137, 347-360. https://doi.org/10.1016/j.jclepro.2016.06.159.

11. Cormier, R., \& Elliott, M. (2017). SMART marine goals, targets and management Is SDG 14 operational or aspirational, is 'Life Below Water' sinking or swimming?. Marine Pollution Bulletin, 123(1-2), 28-33. https://doi.org/10.1016/j.marpolbul.2017.07.060.

12. Gupta, D., \& Garg, A. (2020). Sustainable development and carbon neutrality: Integrated assessment of transport transitions in India. Transportation Research Part D: Transport and Environment, 85, 102474. https://doi.org/10.1016/j.trd.2020.102474.

13. Pamucar, D., Deveci, M., Canitez, F., Paksoy, T., \& Lukovac, V. (2021). A Novel Methodology for Prioritizing Zero-Carbon Measures for Sustainable Transport. Sustainable Production and Consumption, 27, 1093-1112. https://doi.org/10.1016/j.spc.2021.02.016.

14. Decree of the President of Ukraine (2019). On the Goals of Sustainable Development of Ukraine until 2030 (No 722/2019). https://zakon.rada.gov.ua/laws/show/722/2019\#Text.

15. Order of the Cabinet of Ministers of Ukraine (2018). On approval of the National Transport Strategy of Ukraine for the period up to 2030 (No 430-p). https://zakon.rada.gov.ua/laws/show/430-2018-\%D1\%80\#Text.

16. Order of the Cabinet of Ministers of Ukraine (2013). On approval of the Strategy for the development of seaports of Ukraine for the period up to 2038 (No 548-p.). https://zakon.rada.gov.ua/laws/show/548-2013-\%D1\%80\#Text.

17. Law of Ukraine (2020). On inland water transport (No 1054-IX). https://zakon.rada.gov.ua/laws/show/1054-20\#Text.

18. Resolution of the Cabinet of Ministers of Ukraine (2009). On the approval of the Maritime Doctrine of Ukraine for the period up to 2035 (No 1307). https://zakon.rada.gov.ua/laws/show/1307-2009-\%D0\%BF\#Text.

19. Shevchenko, H., Petrushenko, M., Burkynskyi, B., \& Khumarova, N. (2021). SDGs and the ability to manage change within the European green deal: The case of Ukraine, Problems and Perspectives in Management, 19 (1), 53-67. https://doi.org/10.21511/ppm.19(1).2021.05

20. Demianchuk, M., Bezpartochnyi, M., Filipishyna, L., \& Živitere, M. (2021). The model of achieving a balanced balance between economic efficiency and ecological-social responsibility of digitalized enterprise. Journal of Optimization in Industrial Engineering, 14 (1), 63-70. https://doi.org/10.22094/JOIE.2020.677817

21. Bezpartochnyi, M., Britchenko, I., \& Jarosz, P. (2019). Economic diagnostics in ensuring of competitiveness the economic entities. In M. Bezpartochnyi, \& I. Britchenko (Eds.), Conceptual aspects management of competitiveness the economic entities (pp. 1019). Poland, Higher School of Social and Economic.

22. Ilchenko, S. (2019). Risks and threats of providing transport services towards sustainable development. Business and Economics: Collect. of scient. articles of the International Conference (December, 27, Nuremberg), 35-39. http://conferencii.com/files/archive/2019-12.pdf

23. Shemayev, V. (2017). Strategic priorities of the development of the sea ports of Ukraine. Problems and Perspectives of Entrepreneurship Development, 3(2), 9-17. http://nbuv.gov.ua/UJRN/piprp_2017 3\%282\%29 4

24. Korniyenko, O., \& Koshara E. (2017). Organizational and economic bases of Ukrainian seaports functioning in the system of transport service market. Socio-economic research bulletin, 1(62), 84-93. http://vsed.oneu.edu.ua/collections/2017/62/pdf/84-93.pdf

25. Ilchenko, N., \& Kulik A. (2019). Development of transport and logistics system in 
Ukraine. Scientific notes of Taurida National V.I. Vernadsky University Series: Economy and Management, 30 (69), 5, 42-50. DOI: https://doi.org/10.32838/2523-4803/69-5-36

26. State Statistics Service of Ukraine (n.d.). Statistical information. http://www.ukrstat.gov.ua

27. Law of Ukraine (2003). Economic Code of Ukraine (No 436-IV). https://zakon.rada.gov.ua/laws/show/436-15\#Text

28. State Service of Sea and River Transport of Ukraine (n.d.). State ship register of Ukraine. https://marad.gov.ua/ua/poslugi/derzhavnij-sudnovij-reyestr-ukrayini

29. Yale Center for Environmental Law \& Policy (2020). 2020 EPI Results. https://epi.yale.edu/epi-results/2020/component/epi

30. Ministry of Environment Protection and Natural Resources of Ukraine (2020). National report on the state of the environment in Ukraine in 2018. https://mepr.gov.ua/news/35937.html 